\title{
The impact of visual cards on pest populations in greenhouse tomato production
}

\author{
D. Lemic, M. Dvečko, Z. Drmić, H. Virić Gašparić, M. Čačija and R. Bažok \\ University of Zagreb, Faculty of Agriculture, Department for Agricultural Zoology, Zagreb, Croatia
}

\section{Summary}

Control of tomato pests in greenhouses is connected with the difficulties that are related to resistance development, the limited number of available active ingredients, and the accumulation of unwanted and illegal residues in fruits. The increased market demand for tomatoes produced in accordance with integrated pest management principles requires new methods in pest control. One of the alternative methods is mass trapping using colored sticky cards. In a study conducted during 2004 and 2005, a set of blue and yellow sticky cards were placed in an experimental greenhouse area. The goal of the study was to investigate the impact of sticky cards on the population abundance of the most important tomato pests (whiteflies, thrips and aphids) through the entire tomato growing period, in order to determine whether these cards are an effective control tool for key pests in greenhouse production. The method of mass trapping using one yellow and one blue sticky card per 4-5 $\mathrm{m}^{2}$ resulted in high catches and a low abundance of pests on plants, and it had the same efficiency as chemical pest control in preventing damages. Setting up a large number of visual colored cards can be used to control pests and prevent damages in greenhouse tomato production.

Keywords

aphids, blue sticky cards, integrated pest management, thrips, yellow sticky cards, western flower thrips, whiteflies

\section{Introduction}

The fruit of tomato (Solanum lycopersicum Mill.) plant is one of the most common edible commodities in the world today, and it occupies the world's largest category of vegetables, at around $17 \%$. The plant species is native to South America (Mexico) and Central America, but it is commonly planted globally, especially in temperate climates and in greenhouses. The world's largest tomato-producing countries in 2017 were China, with 56.8 million tons of tomatoes, followed by India (18.7 million tons), USA (14.5 million tons), and Turkey (11.9 million tons) (FAO, 2017). The EU produced around 18 million tons of tomatoes in the 2016/2017 campaign, $40 \%$ of which were sold on the fresh market. The remaining volume is processed by the industry. Together, Spain, Italy, the Netherlands, Poland, and France account for $75 \%$ of the tomato production for fresh consumption. This distribution is different for the processing industry, with the Spanish, Italian, and Portuguese productions being the most predominant. These

\section{Significance of this study}

What is already known on this subject?

- Whiteflies and western flower thrips are the most common pests of greenhouse tomatoes. Excessive implication of insecticides for tomato pest control has led to development of resistance, limiting number of permitted active ingredients on market and residues in the fruits. In organic tomato production, chemical control could be effectively replaced by using visual cards as non-pesticidal means of pest control.

What are the new findings?

- Blue and yellow visual cards used for both whiteflies and western flower thrips mass trapping had the same efficiency as chemical pest control in preventing damages on greenhouse tomatoes.

What is the expected impact on horticulture?

- Visual cards can be recommended as an effective non-pesticidal pest management tool in ecological greenhouse tomato production.

countries supply $94 \%$ of the tomatoes used for processing (Eurostat, 2018). In Croatia, tomato was grown on 370 ha with a total yield of 24,571 tons of tomatoes $\left(66.4 \mathrm{tha}^{-1}\right)$ (Statistical Yearbook, 2017).

Successful crop production requires that crop pests and diseases are managed so that their effects on the plants are minimized. Managing pest problems is directed at preventing pest populations from becoming too large and uncontrollable (Portree, 1996). The presence of pests is a fact of crop production, and growers must use all available options and strategies to avoid serious pest problems (Rubatzky and Yamaguchi, 1997).

The most important pests of greenhouse tomatoes globally are whiteflies, thrips, mites and sometimes aphids. Whiteflies (Trialeurodes vaporariorum (Westwood, 1856)) are the most common insect pests of greenhouse tomatoes. Whiteflies damage the plant by sucking the sap from the leaves. Large infestations can cause leaf yellowing and a general decline in the plant (Hussey et al., 1958). Very common pests of greenhouse tomatoes are thrips, which feed by opening wounds on the plant surface and sucking out the contents of the plant cells. The feeding results in small whitish streaks on the leaves and fruit, and it can cause distortions (Shorey and Hall, 1963) in the young developing fruit (Davidson and Peairs, 1966; Howard et al., 1994; Portree, 1996). There are two species of thrips that are common pests of tomato, the western flower thrips (Frankliniella occidentalis (Pergande, 1895)), and the onion thrips (Thrips tabaci Lindeman, 1889) 
(Howard et al., 1994; Portree, 1996). The two-spotted spider mite (Tetranychus urticae Koch, 1836) is a common pest of a number of greenhouse crops (Howard et al., 1994; Portree, 1996). Typical symptoms of two-spotted spider mite infestations include speckling of leaves and fine webbing on the underside of affected leaves (Malais and Ravensberg, 2003). Aphids do not occur in greenhouse tomatoes production every season or might be less present than other pests, what is a seasonally dependable. When infestations occur, they are usually located on plants, close to the veins. The green peach aphid (Myzus persicae Sulzer, 1776) is the most common aphid pest of greenhouse vegetable crops, but there are other aphid species that can become a problem in greenhouse tomatoes. These other aphid species include the melon aphid (Aphis gossypii Glover, 1877), the potato aphid (Macrosiphum euphorbiae (Thomas, 1878)), and the foxglove aphid (Aulacorthum solani Kaltenbach, 1843). In Croatia, more recently, the South American tomato pinworm (Tuta absoluta (Meyrick, 1917)) appears as a serious tomato pest as well (Gotlin Čuljak et al., 2010). Very often, many of those pests are controlled with repeated treatments of insecticides. Over-usage of insecticides leads to the development of resistance in pests, and human and environmental health hazards (Lahiri and Orr, 2017).

Integrated pest management (IPM) is a term that is used to describe an evolving process where cultural, biological, and chemical controls are included in a holistic approach of pest and disease control (Howard et al., 1994; Igrc-Barčić and Maceljski, 2001). Key components of effective pest and disease control programs include crop monitoring (Howard et al., 1994; Portree, 1996). Crop monitoring is continual ongoing surveillance to detect the presence of a pest or disease at the very early stages of development of the disease or pest population, before economic damage occurs (Howard et al., 1994). Blue and yellow sticky cards, placed throughout the crop, are a useful monitoring tool to help to trap and detect pest problems before they become a problem (Howard et al., 1994). Yellow sticky cards are a commonly used method for the population monitoring of many pests (Šimala, 1994). In recent decades, studies of these cards have mainly been focused on how to use them to monitor populations of pest species such as whiteflies, leafminers and aphids (Berlinger, 1980; Byrne et al., 1990; Shen and Ren, 2003; Zhou et al., 2003; Qiu and Ren, 2006; Gu et al., 2008; Moreau and Isman, 2011; Premalatha and Rajangam, 2011). In recent years, yellow sticky cards have also been used as a method for the control of some pests, especially for the control of whiteflies (Lim et al., 2009; Pizzol et al., 2010). Blue sticky cards have often been recommended for the attraction of flower thrips (Matteson and Terry, 1992; Brødsgaard, 1993; Antignus, 2000).

Sticky cards are an important part of the IPM program for greenhouse growers. They are a useful tool to alert growers to the presence of certain insect pests (Lim et al., 2009). Sticky cards can often help to detect early pest infestations more effectively than intensive plant sampling. By using sticky cards, it is possible to keep track of insect population trends, and make more informed and timely pest management decisions (Lu et al., 2012). The sticky cards, if they are cost-effective, are economically reasonable as well as environmentally safe. The present study was carried out to investigate the effect of sticky cards on the population abundance of most important tomato pests throughout the entire tomato growth period, in order to determine whether these cards were an effective control tool for key pests in greenhouse production.

\section{Materials and methods}

\section{Research site}

The investigation was conducted in 2004 and 2005 in an experimental greenhouse and a control greenhouse located in the town of Križevci $\left(46^{\circ} 1^{\prime} 20.525^{\prime \prime} \mathrm{N}, 16^{\circ} 32^{\prime} 46.651^{\prime \prime} \mathrm{E}\right)$ in northern Croatia (Koprivnica-Križevci County). Venlo-type greenhouses of $150 \mathrm{~m}^{2}$ area size were used for tomato production in soil. Gutter height was 4-6 m to accommodate high wire planting systems, thermal screens and supplementary lighting. Greenhouses covering was with polyethylene plastic film.

\section{Host plants}

In the experimental greenhouse, the tomato cultivar Belle F1 was planted in five rows, in both 2004 and 2005. Each row was $30 \mathrm{~m}$ in length. The distance between the rows was $90 \mathrm{~cm}$, and the distance between the plants in a row was $47 \mathrm{~cm}$. In total, 318 (in 2004) and 331 (in 2005) tomato seedlings were planted in the experimental greenhouse, and no chemical treatments were applied there. As a control, tomato Belle F1 seedlings were planted in a separate control greenhouse, in two rows in both years, with the same distances between rows and plants as in the experimental greenhouse. The total surface of the control area was $4.23 \mathrm{~m}^{2}$. In the control greenhouse, classical chemical treatments with insecticides were used. Planting for both the experimental and control greenhouses was done on 5 May 2004 and 16 May 2005.

\section{Monitoring using sticky cards}

Sticky cards were set up in both greenhouses just after tomato planting (7 May 2004; 17 May 2005). In the experimental greenhouse, in both years, seven sticky cards were set at just above plant height in each of the five rows. In the first, third, and fifth rows, yellow cards were set (representing three replicates with 7 subsamples each), while in the second and fourth rows, blue cards were used (representing two replicates with 7 subsamples each). In total, 21 yellow and 14 blue cards were set in the experimental greenhouse (on average one card per $4.3 \mathrm{~m}^{2}$ ). In the control greenhouse, in each row, one blue and one yellow card were set up (in total, two blue and two yellow cards; on average one card per $\mathrm{m}^{2}$ ), also just above plant height. Each row in the control greenhouse represents one replicate. The cards were inspected every seven days until 17 September 2004 and 7 September 2005. The sticky cards were changed each week, and the heights of the cards were adjusted according to plant growth. All cards were inspected using a microscopic loupe, and insects were identified using a determination key (Schmidt, 1970) to species level when possible.

\section{Control greenhouse treatments}

In the control greenhouse, regular chemical control was performed. Details on the chemical treatments are presented in Table 1.

TABLE 1. Chemical control treatments in the tomato control greenhouse.

\begin{tabular}{lll}
\hline Year & Date of application & Insecticide \\
\hline 2004 & 26 June & Beta-cyfluthrin \\
& 27 July & Thiacloprid \\
& 20 August & Beta-cyfluthrin \\
\hline 2005 & 3 July & Beta-cyfluthrin \\
& 6 August & Beta-cyfluthrin \\
\hline
\end{tabular}




\section{Visual plant inspection}

Visual inspections of plants were performed three times per week during the entire investigation period in both greenhouses, as described by the Manual of the Reporting and Forecasting Service (Čamprag, 1983) which are similar with those described in EPPO Guidelines (EPPO, 2009). Ten places (representing ten replicates) were randomly selected in the experimental greenhouse, and on each site, 10 plants were inspected (a total of 100 plants). Depending on the plant growth, the pests present on leaves, flowers, and fruits were detected. In the control greenhouse, four plants in each row (four replicates) were inspected. The number and pest species detected visually were recorded.

\section{Data analyses}

Data on the average catches of specific species, orders, or superfamilies on both types of sticky cards were compared within the experimental and control greenhouses, and between the experimental and control greenhouses, by analysis of variance (ANOVA) (ARM $9^{\circledR}$ GDM software, Revision 9.2014.7) (Gylling Data Management Inc., 2015). The mean separation was estimated by using the least significant difference (LSD) test in order to determine whether sticky cards can provide the same efficiency in pest population reduction as the chemical control. The number of pests that were detected by visual plant inspections in both greenhouses was used to determine the pest population dynamics.

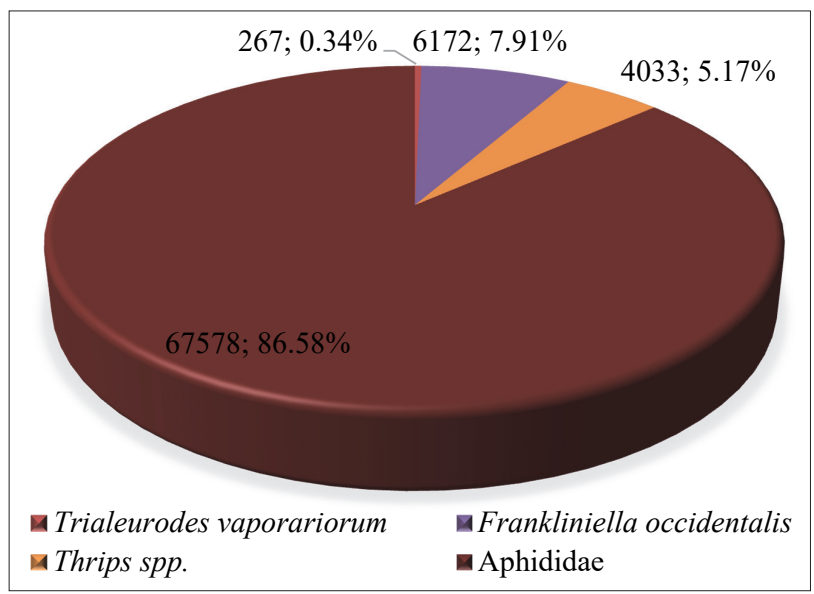

FIGURE 1. Total insect captures in experimental greenhouse in 2004.

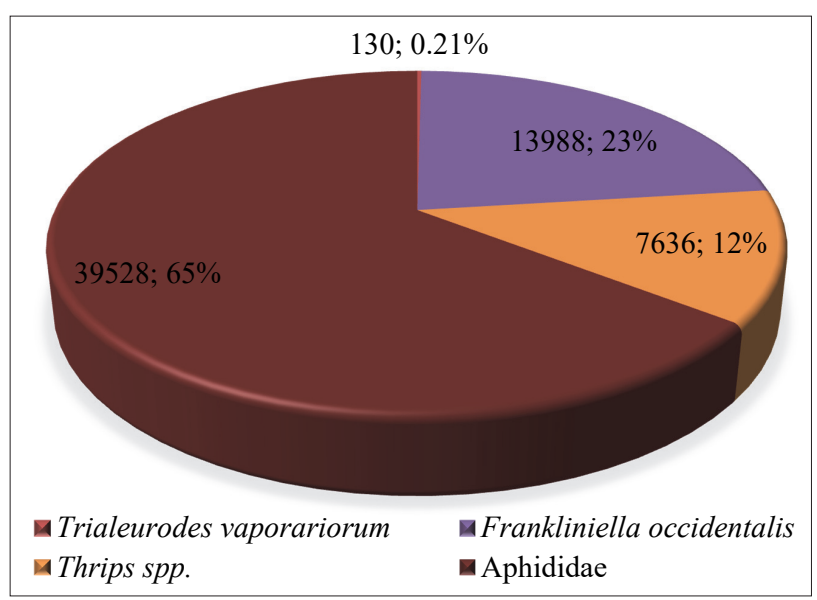

FIGURE 3. Total insect captures in experimental greenhouse in 2005 .

\section{Results}

In 2004, the average number of captures per card was between 2,230 and 3,581 specimens. In 2005, the average captures were between 313 and 1,751 specimens per card. These high numbers of captured insects on colored cards indicate the high potential of sticky cards for attracting and catching different pest species. In experimental and control greenhouses in both years, aphids (superfamily Aphididae) were the dominant pests caught on the sticky cards, and comprised $65-87 \%$ of the total population density. Western flower thrips (Frankliniella occidentalis) followed, with a share of $8-22 \%$ of the total catches. Other specimens of the genus Thrips, which could not be determined to species level, and comprised $5-12 \%$ of the population density. The species $T$. vaporariorum, the greenhouse whitefly, was recorded as having the lowest proportion of the total pest population density, with a share of $0.15-0.34 \%$. All capture details (total number, percentage) in both greenhouses in both vegetation periods have been presented in Figures 1-4.

The greenhouse whitefly population was low in all investigation periods. The average catches on the yellow and blue sticky cards in the experimental and control greenhouses in both investigation years are shown in Table 2. Average catches were very low and they ranged from 0.50 to 10.94 specimens per card. There were no significant differences in catches on the same card type between the experimental and control greenhouses in 2004, and the only significant-

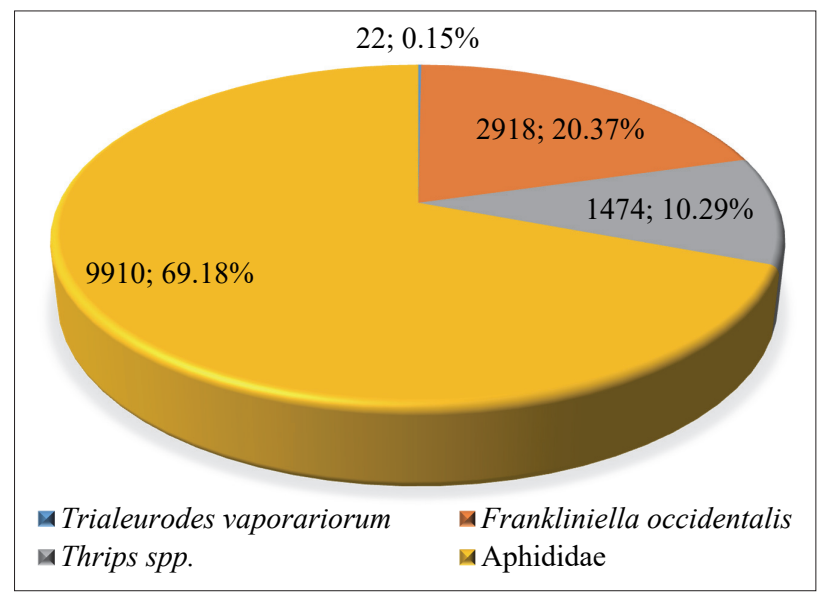

FIGURE 2. Total insect captures in control greenhouse in 2004.

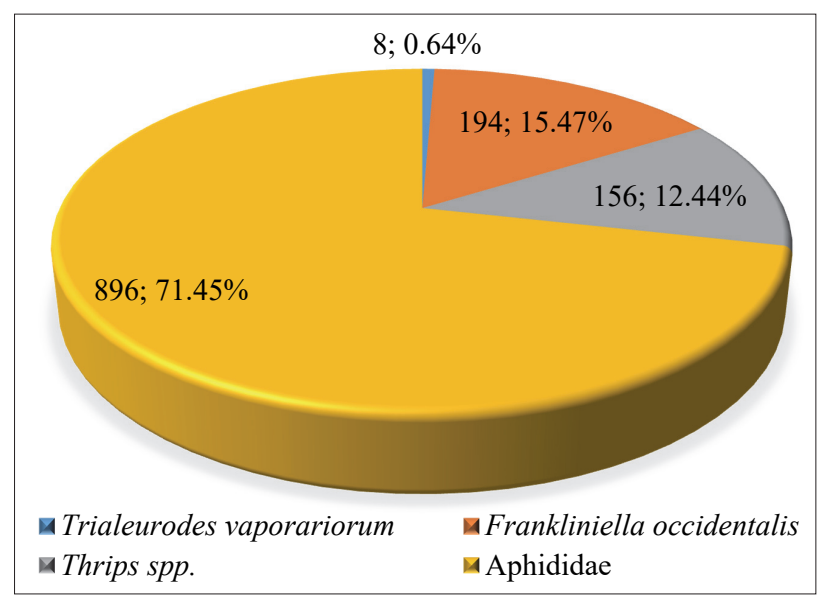

FIGURE 4. Total insect captures in control greenhouse in 2005. 
TABLE 2. The average number of insect species $( \pm$ SD) caught on different sticky card types in experimental and control greenhouses (2004-2005), and the corresponding ANOVA results.

\begin{tabular}{|c|c|c|c|}
\hline \multirow{2}{*}{ Sticky card type } & \multirow{2}{*}{ Greenhouse type } & \multicolumn{2}{|c|}{ Year } \\
\hline & & 2004 & 2005 \\
\hline \multicolumn{4}{|c|}{ Greenhouse whiteflies Trialeurodes vaporariorum (Westwood) } \\
\hline \multirow[t]{2}{*}{ Yellow } & Experimental & $10.94 \pm 5.01 a^{*}$ & $5.62 \pm 3.06 a$ \\
\hline & Control & $8.00 \pm 1.41 \mathrm{a}$ & $3.50 \pm 0.51 b$ \\
\hline \multirow[t]{2}{*}{ Blue } & Experimental & $2.64 \pm 1.25 b$ & $0.86 \pm 0.56 c$ \\
\hline & Control & $3.00 \pm 0.00 b$ & $0.50 \pm 0.71 \mathrm{c}$ \\
\hline \multirow[t]{2}{*}{$\operatorname{LSD} p=0.05^{\star *}$} & & 4.53 & 2.96 \\
\hline & We & rankliniella occidentalis & \\
\hline \multirow[t]{2}{*}{ Yellow } & Experimental & $154.9 \pm 71.26 c^{*}$ & $167.10 \pm 47.76 b$ \\
\hline & Control & $519.5 \pm 81.32 b$ & $39.00 \pm 8.49 b$ \\
\hline \multirow[t]{2}{*}{ Blue } & Experimental & $208.43 \pm 160.65 c$ & $748.50 \pm 368.91 \mathrm{a}$ \\
\hline & Control & $939.5 \pm 132.23 \mathrm{a}$ & $58.00 \pm 7.07 b$ \\
\hline \multirow[t]{2}{*}{$\operatorname{LSD} p=0.05^{* *}$} & & 160.14 & 328.60 \\
\hline & & Thrips spp. & \\
\hline \multirow[t]{2}{*}{ Yellow } & Experimental & $60.56 \pm 24.18 c^{*}$ & $61.92 \pm 16.94 b$ \\
\hline & Control & $196.00 \pm 42.43 b$ & $13.00 \pm 7.07 b$ \\
\hline \multirow[t]{2}{*}{ Blue } & Experimental & $197.21 \pm 118.54$ b & $452.57 \pm 163.66 a$ \\
\hline & Control & $541.00 \pm 59.40 \mathrm{a}$ & $65.00 \pm 4.24 b$ \\
\hline \multirow[t]{2}{*}{$\operatorname{LSD} p=0.05^{\star *}$} & & 113.70 & 147.70 \\
\hline & & family Aphididae & \\
\hline \multirow[t]{2}{*}{ Yellow } & Experimental & $2,373.38 \pm 550.01 a^{*}$ & $1,110.85 \pm 230.99 a$ \\
\hline & Control & $2,351.50 \pm 354.26 a$ & $213.50 \pm 14.85 b$ \\
\hline \multirow[t]{2}{*}{ Blue } & Experimental & $1,266.93 \pm 527.78 b$ & $1,157.14 \pm 300.17 a$ \\
\hline & Control & $2,603.50 \pm 564.98 a$ & $234.50 \pm 21.92 b$ \\
\hline $\operatorname{LSD} p=0.05^{\star \star}$ & & 672.90 & 293.80 \\
\hline
\end{tabular}

*Values followed by the same lowercase letters are not significantly different ( $p>0.05$; LSD test).

** LSD was established by comparisons of catches on all sticky cards in experimental and control greenhouses are represented for each pest separately.

ly lower catches were recorded on yellow sticky cards in control versus experimental greenhouses in 2005. Generally, in both years, significantly more greenhouse whiteflies were caught on yellow sticky cards $\left(\operatorname{LSD}_{(2004)} 0.05=4,527\right.$; $\operatorname{LSD}_{(2005)} 0.05=2,960$ ).

The average numbers of western flower thrips on the yellow and blue sticky cards in the experimental and control greenhouses in both investigation years were much higher than the greenhouse whitefly numbers, and they ranged from 39 to 939 specimens per card. In both years, the highest catches were recorded on the blue sticky cards. Significantly higher catches on both card types were recorded in the control greenhouse in 2004, while in 2005, the highest catch was in the experimental greenhouse (on blue cards).

Similarly to the western flower thrips, in 2004, the population density of other species from the order Thysanoptera was significantly higher on both sticky card types in the control than in the experimental greenhouse. In 2005, there were more specimens determined in the experimental than in the control greenhouse (significantly higher on blue cards). In both greenhouses, in both years, more Thrips spp. were determined on blue than on yellow sticky cards (Table 2).

The superfamily Aphididae was the most abundant group of tomato pests that were determined in this investigation (both greenhouses, both years). The average catches per sticky cards ranged from 213 to 2,603. There were no significant differences in catches on yellow sticky cards between the experimental and control greenhouses in 2004, while in the same year, significantly more aphids were caught on blue sticky cards in the control greenhouse. In 2005, a significantly higher population density was observed in the experimental greenhouse on both card types (Table 2).

Figure 5 presents the results of a weekly visual inspection of tomato plants in 2004, in both greenhouses. During the whole investigation period, only pests from the order Thysanoptera were recorded on the tomato plant organs. The only species determined was the western flower thrips, while the rest of the catch was recorded as Thrips spp. (Figure 5). All of the recorded pests were at very low population numbers in both of the greenhouses throughout the whole tomato growing season. In the experimental greenhouse in the last decade of August, an increasing number of western flower thrips was observed (a maximum of nine individuals per 100 plants). Three chemical treatments did not have any influence on the pest population abundance, as detected by visual inspection on tomato plant organs.

Figure 6 presents results of a weekly visual inspection of the tomato plants in 2005, in both greenhouses. As in 2004, only pests from the order Thysanoptera were observed, with only western flower thrips being determined to the species level (undetermined specimens were marked as Thrips spp.). Similarly to 2004, pests were caught in very high numbers in both greenhouses throughout the whole tomato growing season. The maximum number of Thrips spp. was five individuals per 100 plants, and this was observed in the experi- 


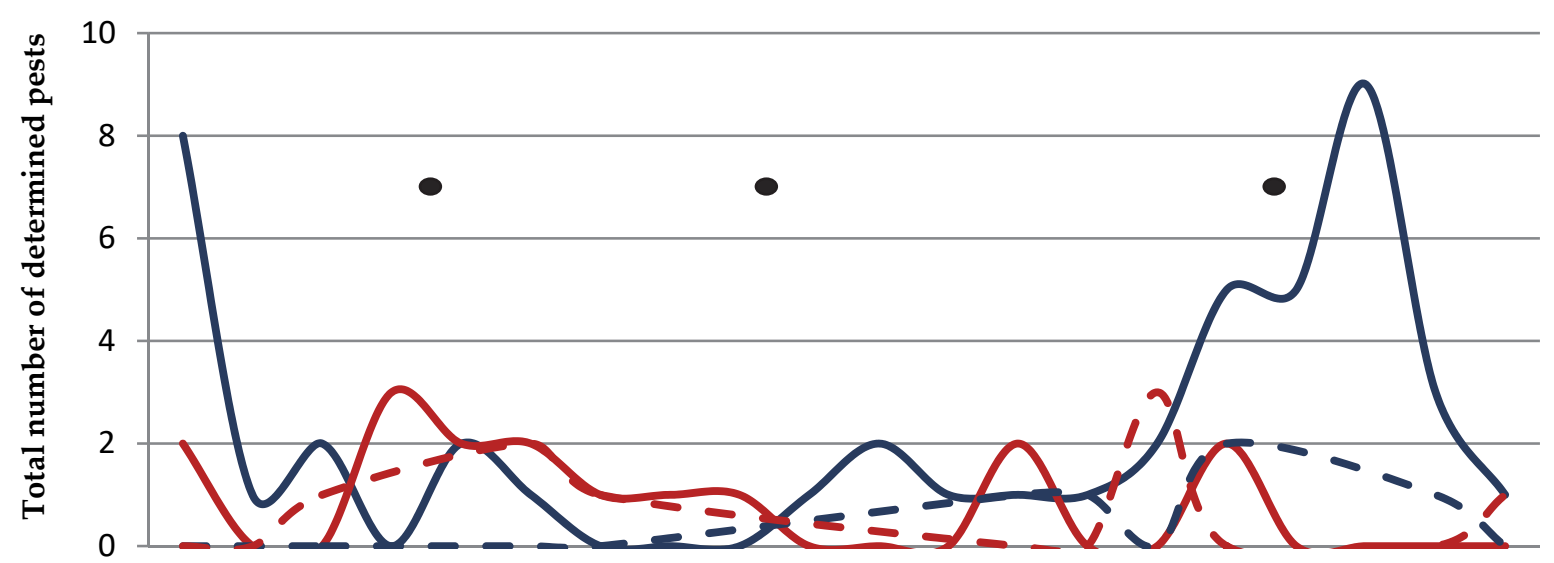

4.6. 9.6. 14.6. 23.6. 28.6. 30.6. 16.7. 19.7. 23.7.30.7. 6.8. 9.8. 11.8. 13.8. 16.8. 18.8. 23.8. 25.8. 27.8. 30.8 .

Visual inspection date

Frankliniella occidentalis E Thrips spp. E - Frankliniella occidentalis $C-$ Thrips spp. C

FIGURE 5. Pest population dynamics as established by visual inspection of tomato plants in 2004, in different greenhouses (• chemical treatment in control greenhouse; C: control greenhouse; E: experimental greenhouse).

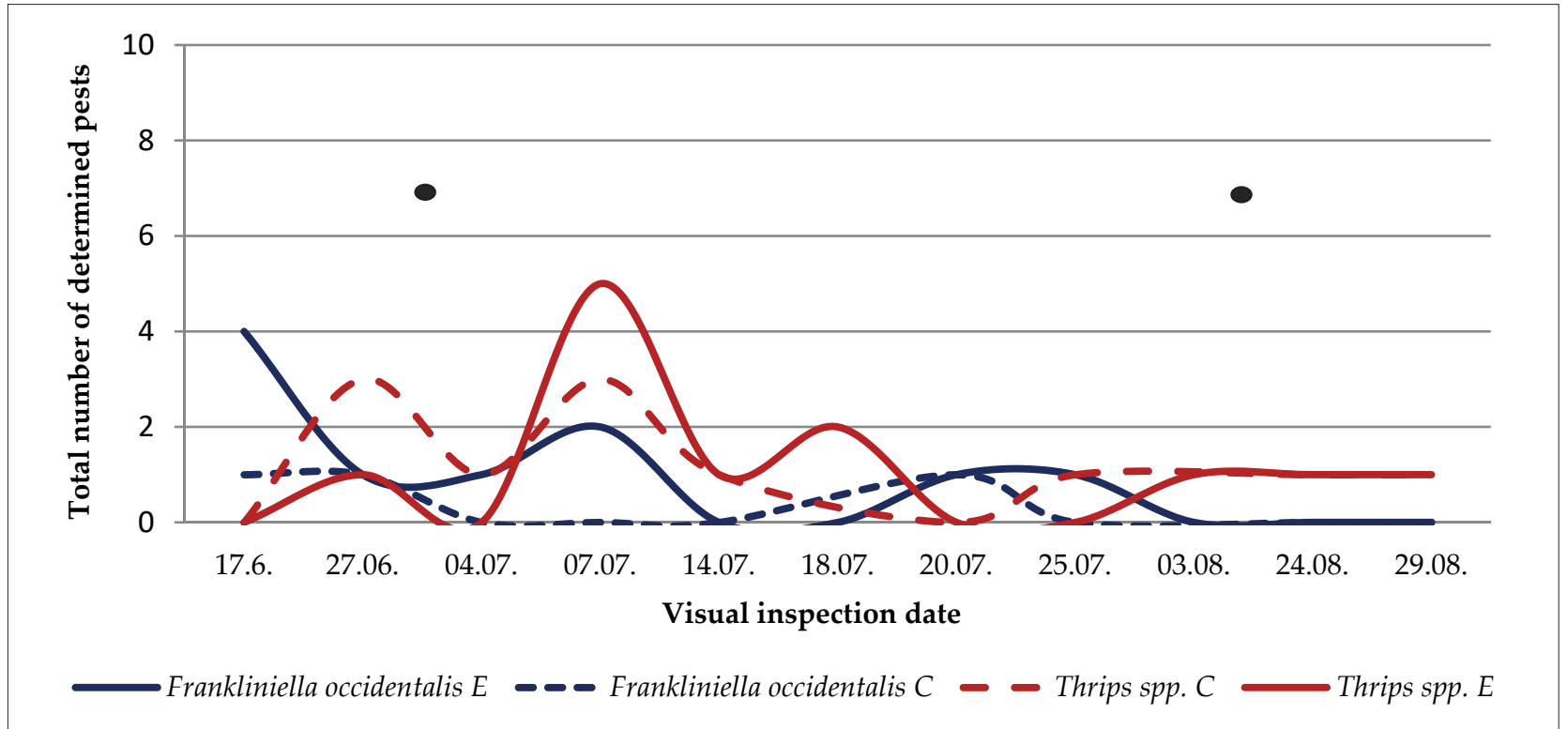

FIGURE 6. Pest population dynamics as established by visual inspection of tomato plants in 2005, in different greenhouses (• chemical treatment in control greenhouse; C: control greenhouse; E: experimental greenhouse).

mental greenhouse in the first 10 days of July. In the control greenhouse, the number of pest individuals did not exceed three. Two chemical treatments did not have any influence on the pest population abundance, as determined by visual inspections on the tomato plant organs.

\section{Discussion}

While colored sticky cards are a common method for monitoring many pests in greenhouses, it has not been shown whether they could be used as a control method. In this study, the impact of yellow and blue sticky cards on the population abundance of observed tomato pests was determined to establish the effectiveness of colored cards in comparison with classical chemical pest control methods.

\section{Insect identification and captures}

The total capture rate of insects on the colored sticky cards was high. Among the observed pest groups, the aphids (superfamily Aphididae) were the dominant pests in both greenhouses. However, aphids were not found on the plant organs, which agrees with some authors that aphids are not common pests of greenhouse tomatoes (Howard et al., 1994; Portree, 1996). When infestations occur, they are usually on plants, close to the veins. Our study glasshouses were quite narrow, and during vegetation growth, the glasshouse vents were open; thus, aphids were probably attracted from the outdoor vegetation. Western flower thrips (Frankliniella occidentalis) occurred in lower abundance, followed by unidentified species from the order Thysanoptera, and greenhouse whitefly (Trialeurodes vaporariorum). While some authors 
did not find differences in captures on cards that were set to different levels (Atakan and Canhil, 2004), others observed that pest catches on cards can depend on card height (Igrc Barčić and Maceljski, 2001; Maceljski, 2002). Accordingly, in this research, cards were set at above plant height, and they were placed higher up as the tomatoes grew. The observed species in the present study, Trialeurodes vaporariorum, Frankliniella occidentalis, Thrips spp., and Aphididae are among the most economically important pests in tomato production (Rice Mahr et al., 2001).

\section{The influence of card color on attractiveness to pests}

There are numerous studies showing the greater attractiveness of yellow colors for greenhouse whitefly (Allsopp, 2010; Igrc Barčić and Maceljski, 2001; Kim et al., 2001; Maceljski, 2002; Chen et al., 2004a, b). In this study, it was confirmed that significantly more whiteflies were captured on yellow than on blue sticky cards (Table 2). Nevertheless, in general, the population of whiteflies was very low.

The capture of western flower thrips in 2004 was higher in the control, compared to the experimental greenhouse, indicating that insecticide treatments did not successfully reduce the population of this pest. In 2005 , the situation was the opposite; more pests were recorded in the experimental compared with the control glasshouse, indicating that insecticide treatments (two treatments with pyrethroids) resulted in successful control. Many researchers have stated that the blue cards are better for thrips attraction (including western flower thrips) (Šimala, 1994; Maceljski, 2002; Maceljski et al., 2004; Chen et al., 2004a, b; Allsopp, 2010). However, some authors have stated that males are more attracted to yellow colors and females to blue (Gillespie and Vernon, 1990). Considering that the thrips mostly reproduce parthenogenetically (Anon., 1988), males are very rare in the population, and according to data, the sexual index is ㅇ15 : o1 (Arzone et al., 1989). Thus, the population mostly consists of females, which react better to the blue color (Gillespie and Vernon, 1990). This fact is confirmed by our results from 2005, but in 2004 no differences were recorded between the yellow and blue cards in the experimental glasshouse, while in the control glasshouse, blue cards caught significantly more western flower thrips. Other species from the order Thysanoptera were also captured in higher abundance on the blue cards.

The aphid population was high in both glasshouses in 2004. In 2005, the aphid population in the experimental glasshouse was significantly higher than in the control glasshouse. The aphids were more attracted to the yellow color (Igrc Barčić and Maceljski, 2001; Maceljski, 2002). In contrast, some researchers showed that the aphids do not have a clear preference for colors (Yudin et al., 1987). In this study, the capture rate of the aphids was very high, although aphids are not particularly common or important tomato pests in greenhouses. In this research, we did not show that significantly more aphids were attracted to yellow than to blue cards. In 2004, yellow traps in the experimental glasshouse caught more aphids compared to blue cards, while in the control glasshouse, there were no differences in capture between the two trap types. In 2005, no significant differences were observed between the glasshouses for captures on yellow or blue sticky cards. However, the aphid capture rate was significantly higher in the experimental compared to the control glasshouse.

\section{Visual inspections of tomato plants}

On the colored cards, the population of winged adult pests was monitored. Damage to the plants could have been made by larvae or by the wingless stages of pests. These development stages cannot be observed on the colored cards, and their presence has to be determined by visual inspection of the plants (Čamprag, 1983; Maceljski, 2002). Visual inspection was performed to establish the level of plant infestation in the experimental and control greenhouses. By visual inspection, only pests from the order Thysanoptera (including western flower thrips) have been recorded. The abundance of these pests was very low in both greenhouses and in both research years (Figures 1 and 2). In both years, in the experimental greenhouse, a slightly higher number of pests were observed in the visual inspections, compared to the control greenhouse. In all cases, there was no visible damage to the plants. The absence of damage in both greenhouses can be explained by the good effect of the treatments, both the classical chemical insecticides and the mass trapping by the colored cards. It is obvious that both treatments successfully reduced the population of tomato pests.

\section{Colored cards versus chemical treatments}

In the experimental greenhouse, only mass trapping of the pests with colored sticky cards was performed, while in the control greenhouse, chemical pest control was used along with the sticky cards. The hypothesis of this research was that mass trapping of pests in the experimental glasshouse would result in a higher number of pests being caught on the cards compared to the control glasshouse (due to the fact that in the control glasshouse, the insect population has been reduced by insecticide application), and with the same level of insect infestation.

The greenhouse whitefly, the most important tomato pest (Maceljski, 2002), showed low densities in both years, and there were no differences in captures between the experimental and control greenhouses. The only exception to this was the slightly lower density of whiteflies in the control greenhouse in 2005 on the yellow sticky cards. The chemical treatments did not have a significant influence on the greenhouse whitefly density, because the captures on the sticky cards in both greenhouses were similar or the same throughout the whole investigation period. In the control greenhouse in 2004, a higher density of western flower thrips and other Thrips spp. was observed, while in 2005, the opposite situation occurred. Three chemical treatments in 2004 did not have any better effectiveness on the thrips population in the control greenhouse, than with massive catches with colored cards. In 2005, only two chemical treatments provided better control against thrips in tomato production. However, visual inspections did not confirm a better effect from the chemical control when comparing only with sticky card catches. The most abundant pests in both years and both greenhouses were aphids, and their densities did not significantly differ between greenhouses in 2004. In 2005, more aphids were observed in the experimental greenhouse, suggesting a higher effectiveness of chemical control.

The results showed the absence of pests on plants (as established by visual inspections), and also indicated that both methods provided good results. In the case of a control greenhouse, the sticky card catches amended the effectiveness of the chemical treatments. The results showed that a large number of colored cards (one card per 4-5 $\mathrm{m}^{2}$ ) in a greenhouse can successfully decrease the number of pests. The use of a combination of yellow and blue cards appears 
to be the best option because it expands the "spectrum" of insect catching.

The cost of such a measure is higher compared to the cost of insecticide application. The price of the cards on the market in Croatia is approximately $1 €$ (for one yellow and one blue card). This means that for the protection of $1,000 \mathrm{~m}^{2}$ of tomato plants, a farmer should invest $200.00 €$ per card setting. Taking into account that the cards should be replaced regularly, it is obvious that the price would be much higher compared to insecticide application, which is approximately $10 €$ per treatment. Even though the findings of this research suggest that yellow and blue sticky cards can be used as an effective method for the control of tomato pests, this method would probably be more likely considered by organic tomato producers, due to the fact that the prices for organically produced products are higher.

\section{Conclusions}

Setting up a large number of visual colored sticky cards in a greenhouse tomato production has resulted in a high catch of pests, and pest population reduction. Both types of colored cards proved to be attractive to the most important tomato pests: greenhouse whitefly, western flower thrips and Thrips spp., and aphids. The method of mass trapping using one yellow and one blue sticky card per 4-5 $\mathrm{m}^{2}$ had the same efficiency as chemical pest control in preventing damages. Setting up a large number of visual colored cards can be used to control pests and prevent damages in greenhouse tomato production. Due to the high prices of the sticky cards, and due to the need for the regular replacement of the cards, the price of this control method would be high. Therefore, it can be recommended as an effective non-pesticidal method in ecological greenhouse tomato production.

\section{Acknowledgments}

We give great gratitude to family farm Volf for providing permission and access to their greenhouses where the research was conducted.

\section{References}

Allsopp, E. (2010). Investigation into the apparent failure of chemical control for management of western flower thrips, Frankliniella occidentalis (Pergande), on plums in the Western Cape Province of South Africa. Crop Prot. 29, 824-831. https://doi.org/10.1016/j. cropro.2010.03.009.

Anon. (1988). Frankliniella occidentalis. Biology and control. EPPO 91, 1-36.

Antignus, Y. (2000). Manipulation of wavelength-dependent behaviour of insects: an IPM tool to impede insects and restrict epidemics of insect-borne viruses. Virus Res. 71, 213-220, https:// doi.org/10.1016/S0168-1702(00)00199-4.

Arzone, A., Alma, A., and Rapetti, S. (1989). Frankliniella occidentalis (Perg.) (Thysanoptera, Thripidae) nuovo fitomizo delle serre in Italia. Inf. Fitopatol. 10, 43-48.

Atakan, E., and Canhilal, R. (2004). Evaluation of yellow sticky traps at various heights for monitoring cotton insect pests. J. Agric. Urban Entomol. 21, 15-24.

Berlinger, M.J. (1980). A yellow sticky trap for whiteflies: Trialeurodes vaporariorum and Bemisia tabaci (Aleurodidae). Entomol. Exp. Appl. 27, 98-102, https://doi.org/10.1111/j.1570-7458.1980.tb02952.x.

Brødsgaard, H.F. (1993). Monitoring thrips in glasshouse pot plant crops by means of blue sticky traps. IOBC/WPRS Bull. 16, 29-32.
Byrne, D.N., Bellows, T.S., and Parrell, M.P. (1990). Whiteflies in agricultural systems. In Whiteflies: Their Bionomics, Pest Status and Management, D. Gerling, ed. (Andover, UK: Intercept Ltd.), p. 227261.

Čamprag, D. (1983). Metode utvrđivanja rasprostranjenosti i brojnosti štetočina u ratarstvu i povrtarstvu. In Priručnik izvještajne i prognozne službe zaštite poljoprivrednih kultura, D. Čamprag, ed. (Beograd, Republic of Serbia: Savez društava za zaštitu bilja Jugoslavije), p. 40-65.

Chen, T.Y., Chu, C.C., Fitzgerald, G., Natwick, E.T., and Henneberry, T.J. (2004a). Trap evaluations for thrips (Thysanoptera: Thripidae) and hoverflies (Diptera: Syrphidae). Environ. Entomol. 33, 1416-1420, https://doi.org/10.1603/0046-225X-33.5.1416.

Chen, T.Y., Chu, C.C., Henneberry, T.J., and Natwick, E.T. (2004b). Catching thrips (Thysanoptera: Thripidae) with various traps. In Proceedings of the Beltwide Cotton Conferences, D.A. Richter, ed. (Memphis, USA: National Cotton Council of America), p. 1703-1705.

Davidson, R.H., and Peairs, L.M. (1966). Insect Pests of Farm, Garden and Orchards (New York, USA: John Wiley and Sons).

EPPO (2009). PP 1/36(3): Whiteflies (Trialeurodes vaporariorum, Bemisia tabaci) on protected crops. EPPO Bulletin 39, 218-220. https://doi.org/10.1111/j.1365-2338.2009.02293.x.

Eurostat (2018). Available online: http://ec.europa.eu/eurostat/ statistics-explained/index.php/Agricultural_production_-_crops (accessed July 5, 2018).

Food and Agriculture Organization of the United Nations (2018). Available online: http://faostat3.fao.org/ (accessed July 5, 2018).

Gillespie, D.R., and Vernon, R.S. (1990). Trap catch of western flower thrips (Thysanoptera: Thripidae) as affected by color and height of sticky traps in mature greenhouse cucumber crops. J. Econ. Entomol. 83, 971-975. https://doi.org/10.1093/jee/83.3.971.

Gotlin Čuljak, T., Ražov, J., Gomboc, S., Grubišić, D., and Juran, I. (1994). Prvi nalaz lisnog minera rajčice Tuta apsoluta Povolny, 1994 (Lepidoptera: Gelechiidae) u Hrvatskoj. Glasilo biljne zaštite 4, 273281.

Gu, X.S., Bu, W.J., Xu, W.H., Bai, Y.C., Liu, B.M., and Liu, T.X. (2008). Population suppression of Bemisia tabaci (Hemiptera: Aleyrodidae) using yellow sticky traps and Eretmocerus $n r$. rajasthanicus (Hymenoptera: Aphelinidae) on tomato plants in greenhouses. Insect Sci. 15, 263-270. https://doi.org/10.1111/j.17447917.2008.00209.x.

Gylling Data Management Inc. (2015). ARM 9® GDM Software. Revision 9.2014.7 (Brookings, South Dakota, USA).

Howard, R.J., Garland, J.A., and Seaman, W.L. (1994). Diseases and Pests of Vegetable Crops in Canada: An Illustrated Compendium (Ottawa, Canada: The Canadian Phytopathological Society and the Entomological Society of Canada).

Hussey, N.W., Parr, W.J., and Gurney, B. (1958). The effect of whitefly populations on the cropping of tomatoes. Glasshouse Crops Res. Inst. Annu. Rep., p. 79-86.

Igrc Barčić, J., and Maceljski, M. (2001). Ekološki prihvatljiva zaštita bilja od štetnika (Čakovec, Croatia: Zrinski).

Kim, J.K., Park, J.J., Park, H., and Cho, K. (2001). Unbiased estimation of greenhouse whitefly, Trialeurodes vaporariorum, mean density using yellow sticky trap in cherry tomato greenhouses. Entomol. Exp. Appl. 100, 235-243. https://doi.org/10.1046/j.1570-7458.2001.00868.x.

Lahiri, S., and Orr, D. (2017). Biological control in tomato production systems: Theory and practice. In Sustainable Management of Arthropod Pests of Tomato, W. Wakil, G.E. Brust, and T.M. Perring, eds. (Cambridge, Mass., USA: Academic Press), p. 253-267. https:// doi.org/10.1016/B978-0-12-802441-6.00011-5. 
Lim, U.T., and Mainali, B.P. (2009). Optimum density of chrysanthemum flower model traps to reduce infestations of Frankliniella intonsa (Thysanoptera: Thripidae) on greenhouse strawberry. Crop Prot. 28, 1098-1100. https://doi.org/10.1016/j. cropro.2009.07.012.

Lu, Y., Bei, Y., and Zhang, J. (2012). Are yellow sticky traps an effective method for control of sweetpotato whitefly, Bemisia tabaci, in the greenhouse or field? J. Insect Sci. 12, 113. https://doi. org/10.1673/031.012.11301.

Maceljski, M. (2002). Poljoprivredna Entomologija (Čakovec, Croatia: Zrinski).

Maceljski, M., Cvjetković, B., Ostojić, Z., Igrc Barčić, J., Pagliarini, N., Oštrec, Lj., Barić, K., and Čizmić, I. (2004). Štetočinje Povrća (Čakovec, Croatia: Zrinski).

Malais, M.H., and Ravensberg, W.J. (2003). Knowing and Recognizing: The Biology of Glasshouse Pests and Their Natural Enemies, B.V. Koppert, ed. (Berkel en Rodenrijs, the Netherlands).

Matteson, N.A., and Terry, L.I. (1992). Response to color by male and female Frankliniella occidentalis during swarming and nonswarming behavior. Entomol. Exp. Appl. 63, 187-201. https://doi. org/10.1111/j.1570-7458.1992.tb01573.x.

Moreau, T.L., and Isman, M.B. (2011). Trapping whiteflies? A comparison of greenhouse whitefly (Trialeurodes vaporariorum) responses to trap crops and yellow sticky traps. Pest Mgt. Sci. 67 408-413. https://doi.org/10.1002/ps.2078.

Pizzol, J., Nammour, D., Hervouet, P., Bout, A., Desneux, N., and Mailleret, L. (2010). Comparison of two methods of monitoring thrips populations in a greenhouse rose crop. J. Pest Sci. 83, 191196. https://doi.org/10.1007/s10340-010-0286-5.

Portree, J. (1996). Greenhouse Vegetable Production Guide for Commercial Growers (Victoria, BC, Canada: Province of British Columbia Ministry of Agriculture, Fisheries and Food).

Premalatha, K., and Rajangam, J. (2011). Efficacy of yellow sticky traps against greenhouse whitefly, Trialeurodes vaporariorum (Westwood) (Aleyrodidae: Hemiptera) in gerbera. J. Biopesticides 4, 208-210.

Qiu, B.L., and Ren, S.X. (2006). Using yellow sticky traps to inspect population dynamics of Bemisia tabaci and its parasitoids. Chin. Bull. of Entomol. 43, 53-56.

Rice Mahr, S., Cloyd, R.A., Mahr D.L., and Sadof, C.S. (2001). Biologica Control of Insects and Other Pests of Greenhouse Crops (Madison, WI., USA: University of Wisconsin-Extension, Cooperative Extension).

Rubatzky, V.E., and Yamaguchi, M. (1997). World Vegetables: Principles, Production and Nutritive Values (New York, USA: Chapman \& Hall).

Schmidt, L. (1970). Tablice za Determinaciju Insekata: Priručnik za Agronome, Šumare i Biologe (Zagreb, Croatia: University of Zagreb Faculty of Agriculture).

Shen, B.B., and Ren, S.X. (2003). Yellow card traps and its effects on populations of Bemisia tabaci. J. South China Agric. Univ. 24, 40-43.

Shorey, H.H., and Hall, I.M. (1963). Toxicity of chemical and microbial insecticides to pest and beneficial insects on poled tomatoes. J. Econ. Entomol. 56, 813-817. https://doi.org/10.1093/jee/56.6.813.

Šimala, M. (1994). Frankliniella occidentalis (Perg.) (Thysanoptera: Thripidae) novi štetnik povrća i ukrasnog bilja u Hrvatskoj. M.Sc. thesis (Zagreb, Croatia: University of Zagreb).

Statistical Yearbook of the Republic of Croatia (2018). Available online: https://www.dzs.hr/Hrv_Eng/ljetopis/2017/sljh2017.pdf (accessed July 5, 2018).
Yudin, L.S., Mitchell, W.C., and Cho, J.J. (1987). Color preference of thrips (Thysanoptera: Thripidae) with reference to aphids (Homoptera: Aphididae) and leafminers in Hawaiian lettuce farms. J. Econ. Entomol. 80, 51-55. https://doi.org/10.1093/jee/80.1.51.

Zhou, F.C., Du, Y.Z., Sun, W., Yao, Y.L., Qin, T.Y., and Ren, S.X. (2003). Impact of yellow trap on sweetpotato whitefly Bemisia tabaci (Gennadius) in vegetable fields. Entomol. J. of East China 12, 96-100.

Received: Oct. 10, 2018

Accepted: Mar. 18, 2019

Address of authors:

Darija Lemic, Marija Dvečko, Zrinka Drmić,

Helena Virić Gašparić, Maja Čačija* and Renata Bažok University of Zagreb, Faculty of Agriculture, Department for Agricultural Zoology, Svetošimunska 25, 10000 Zagreb, Croatia

* Corresponding author; E-mail: mcacija@agr.hr Tel.: +385-1-2393-621 